\title{
THE FAMILY WAR
}

My father made meals underwater while the war went on. He stirred enormous pots of s.o.s. in the belly of a ship, thinking of me held upside down, he flipped an extra dash of salt into the stew as the big guns pushed and recoiled like a woman in labor.

There was a war, the smell of irons steaming in small apartments and sons aiming wooden rifles at each other.

There was ma grown big bellied with me facing the windy sea, that double image of waiting, dad, a cold shuttling ocean throwing up stones and salt.

But you came back and blocked up all the windows in the house until my brother threw the first punch through the wall. Then you felt at home, coming at us in the darkness like a grey slug from the big guns ready to explode.

\section{THE ANT MAKES PROGRESS TOWARDS HIMSELF}

If the page isn't a hole for escape, you learn to fill the entrance with stones and fear the thunder that comes rolling to the roots of your progress. Sometimes, isn't it always night, you'll carve your rest into the wall and yell is this enough? The same thin yell that told you where to dig comes back. Nothing matters until another tunnel breaks through yours. Then the shock is seeing someone with your face; that there's so little left of it, it's grown so dark, it is the blackness shining at the end. 